\title{
Chemical and anti-ulcer evaluation of Jodina rhombifolia (Hook. \& Arn.) Reissek extracts
}

\author{
Jarbas A. Montanha, ${ }^{*, 1}$ Eloir P. Schenkel, ${ }^{2}$ Alexandre T. Cardoso-Taketa, ${ }^{3}$ Ana P. Dresch, ${ }^{1}$ \\ Augusto Langeloh, ${ }^{4}$ Eliane Dallegrave ${ }^{4}$
}

\author{
${ }^{I}$ Departamento de Produção de Matéria-Prima, Faculdade de Farmácia, Universidade Federal do Rio Grande \\ do Sul, Av. Ipiranga 2752, 90610-000 Porto Alegre-RS, Brazil, \\ ${ }^{2}$ Departamento de Ciências Farmacêuticas, Universidade Federal de Santa Catarina, Campus Universitário \\ Trindade, 88040-900 Florianópolis-SC, Brazil, \\ ${ }^{3}$ Centro de Investigación en Biotecnología, Universidad Autónoma del Estado de Morelos, Avenida Universidad \\ 1001, Col. Chamilpa, Cuernavaca, Morelos 62210, México, \\ ${ }^{4}$ Departamento de Farmacologia, Instituto de Ciências Básicas da Saúde, Universidade Federal do Rio Grande \\ do Sul, Av. Sarmento Leite 500, 90040-060, Porto Alegre-RS, Brasil
}

\begin{abstract}
RESUMO: "Estudo químico e da atividade antiúlcera de Jodina rhombifolia (Hook. \& Arn.) Reissek". Jodina rhombifolia (Hook. \& Arn.) Reissek (Santalaceae) é uma espécie vegetal nativa do Sul do Brasil e usada externamente na medicina popular para o tratamento de úlcera na pele. Neste trabalho foi estudada a atividade antiúlcera gástrica em ratos usando como indutor ácido clorídrico/etanol. Os extratos hidroetanólico e aquoso apresentaram atividade antiúlcera no modelo utilizado. A análise cromatográfica do extrato hidroetanólico das folhas indicou a presença de C-glicosilflavonóides. Da fração n-butanólica obtida por extração seqüencial do extrato hidroetanólico foi isolada e identificada por métodos espectroscópicos a vicenina-2 como substância majoritária. Desta fração também foram identificados por CCD bidimensional, com auxílio de substâncias de referência, outros três C-glicosídeos: vitexina, orientina e swertisina.
\end{abstract}

Unitermos: Jodina rhombifolia, Santalaceae, antiúlcera, C-glicosilflavonóides, vicenina-2.

\begin{abstract}
Jodina rhombifolia (Hook. \& Arn.) Reissek (Santalaceae) is a medicinal plant popularly used as an anti-ulcer medicine. The plant native from Southern Brazil was chemically investigated and tested for its in vivo gastric anti-ulcer property by chloride acid/ethanol model. The chromatographic analysis of the hydroethanol extract of its leaves revealed the presence of C-glycosylflavonoids. From the $n$-butanol fraction of the hydroethanol extract of its aerial parts, vicenin-2 was isolated as the main component and identified by spectroscopic methods; and, a direct comparison with authentic samples was made. This fraction afforded three other C-glycosylflavonoids: vitexin, orientin and swertisin; all of them identified by direct comparison with authentic samples. We found that the oral administration of aqueous and hydroethanolic extracts led to a significant decrease in the ulcer index.
\end{abstract}

Keywords: Jodina rhombifolia, Santalaceae, anti-ulcer, C-glycosylflavonoids, vicenin-2.

\section{INTRODUCTION}

Jodina rhombifolia Hook. \& Arn, (Santalaceae) is a plant native to Argentina, Bolivia, Southern Brazil, Paraguay and Uruguay, known as "cancorosa-de-trêspontas", "erva-cancorosa", "espinheira-de-três pontas" or only "cancorosa" (D'Avila, 1910; Simões et al., 1998). Its aerial parts are employed in folk medicine, mainly for the treatment of digestive problems and, externally to heal skin ulcers and other skin diseases as rash, carcinoma or nasal polyps (D'Avila, 1910; Corrêa, 1969; Simões et al., 1998). Notwithstanding the wide utilization in different regions of South America, chemical and pharmacological studies of Jodina rhombifolia are rather scarce (Biavatti et al., 2007).

In the present study, we describe the investigation of the anti-ulcer activity of aqueous and hydroalcoholic extracts obtained from the aerial parts of Jodina rhombifolia, together with the chemical analysis of these polar extracts.

\section{MATERIAL AND METHODS}

\section{Plant material and extraction}

The aerial parts of Jodina rhombifolia Hook. \& Arn. Reissek were collected in Porto Alegre, RS, Brazil. The voucher specimen is in a deposit in the Herbarium 
of the Universidade Federal do Rio Grande do Sul (ICN/ UFRGS) (number 87566). The air-dried and powdered plant material was extracted with $\mathrm{EtOH} / \mathrm{H}_{2} \mathrm{O}(60: 40)$ $(\mathrm{drug} /$ solvent ratio $=1: 10 \mathrm{w} / \mathrm{v})$ by maceration. The aqueous extract was prepared with dried plant material by infusion (drug/solvent ratio $=1: 10 \mathrm{w} / \mathrm{v})$ with hot distilled water. The extracts were evaporated to dryness under reduced pressure.

\section{General procedure}

UV data were recorded on a UV-Vis-2201 Recording Spectophotometer Shimadzu. ${ }^{1} \mathrm{H} \quad(500$ $\mathrm{MHz})$ and ${ }^{13} \mathrm{C}(125.7 \mathrm{MHz}) \mathrm{NMR}$ spectra (DEPT, ${ }^{1} \mathrm{H}-$ ${ }^{1} \mathrm{H}$ COSY, HMBC and HMQC) were recorded on a Bruker AVANCE AMX 500 spectrometer equipped with a $5 \mathrm{~mm}$ multinuclear inverse probehead with z-shielded gradient. MeOD was used as solvent. TLC was performed on precoated aluminium sheets (Silica gel GF254 $0.25 \mathrm{~mm}$, Merck, Germany) with detection provided by UV light ( 254 and $365 \mathrm{~nm}$ ) and by spraying with Natural Product Reagent A (Roth). Sephadex LH20 (Pharmacia) and Avicel microcrystalline cellulose were used in the compound isolation.

\section{Isolation of compounds}

The hydroethanol extract was concentrated and the resulting phase was successively extracted with petrol ether, ethyl acetate and n-butanol. The n-butanol fraction $(2.5 \mathrm{~g})$ was chromatographed on a $120 \mathrm{~g}$ microcrystalline cellulose column using acetic acid:water (10:90 and 15:85 v/v) to yield compound 1 $(150 \mathrm{mg})$ as the main component that was cleaned over repeated chromatography on a Sephadex LH-20 column using methanol as a mobile phase, resulting in $100 \mathrm{mg}$ of pure compound $\mathbf{1}$. Compound $\mathbf{1}$ was also analyzed by UV, ${ }^{1} \mathrm{H}$ NMR and ${ }^{13} \mathrm{C}$ NMR spectroscopy. Other three compounds were identified by two dimensional TLC on silica gel (ethyl acetate: formic acid: acetic acid:methyl ethyl ketone:water, 50:7:3:30:10 and n-butanol:acetic acid:water, 40:10:50. upper phase) and compared with authentic samples using vitexin, isovitexin, vicenin, vicenin-2, swertisin, isoswertisin, spinosin, orientin and isoorientin as reference substances.

\section{HCl / ethanol-induced gastric lesions}

The $\mathrm{HCl} /$ ethanol-induced gastric lesions modified model (Yesilada et al., 1997) was used by verified anti-ulcer activity of the hydroethanol and aqueous extracts of aerial parts of Jodina rhombifolia.

Female Wistar rats weighing between 200$250 \mathrm{~g}$ were fasted for $24 \mathrm{~h}$ with water ad libitum before ulcer induction. The estral cycle phase of the rats was evaluated by vaginal cytology and only females in diestrus phase were examined. The animals were housed in a ventilated room, at a temperature of $22 \pm 2$ ${ }^{\circ} \mathrm{C}$, under a $12 \mathrm{~h}$ light (9:00 a.m. to 9:00 p.m.)/12h dark cycle. The assay was carried out between 9:00 a.m. and 6:00 p.m. The study was approved by the Committee for Ethics in Animal Research of our University (protocol $n^{\circ}$ 200254) and all experiments were carried out in accordance with the norms of the Brazilian College of Animal Experimentation.

All treatments were administered orally in a volume of $10 \mathrm{~mL} / \mathrm{kg}$. The animals were randomized into six groups of eight animals each. Group I, serving as control, received distilled water while animals of group II ranitidine $(100 \mathrm{mg} / \mathrm{kg})$. The dried aqueous extract in doses of 250 and $750 \mathrm{mg} / \mathrm{kg}$ was administered to groups III and IV, respectively. The animals of groups $\mathrm{V}$ and VI received 250 and $750 \mathrm{mg} / \mathrm{kg}$ of hydroethanol extract, respectively. Thirty minutes later, ulceration was induced by administration of a $0.3 \mathrm{M}$ solution of $\mathrm{HCl}$ in $60 \%(\mathrm{v} / \mathrm{v})$ ethanol $(1 \mathrm{~mL} / \mathrm{kg})$. After one hour, the animals were killed by decapitation, the stomachs removed and opened along the greater curvature. All stomachs were washed with a $\mathrm{NaCl} 0.9 \%$ solution (10 $\mathrm{ml} / \mathrm{stomach}$ ). The number of rats with ulcers and the length of each lesion were determined using a stereo microscope. The scores according with the size of the ulcers, adapted from Williamson et al. (1996), are the following: None ulcer (score 0); Ulcers $<2 \mathrm{~mm}$ (score 1); One ulcer $\geq 2 \mathrm{~mm}$ and $<5 \mathrm{~mm}$ (score 2); More than one $\geq 2 \mathrm{~mm}$ and $<5 \mathrm{~mm}$ (score 3); One ulcer $\geq 5 \mathrm{~mm}$ and $<8 \mathrm{~mm}$ (score 4); More than one $\geq 5 \mathrm{~mm}$ and $<8$ $\mathrm{mm}$ (score 5); One ulcer $\geq 8$ and $<10 \mathrm{~mm}$ (score 6); More than one $\geq 8$ and $<10 \mathrm{~mm}$ (score 7); One ulcer $\geq 10 \mathrm{~mm}$ (score 8); More than one $\geq 10 \mathrm{~mm}$ (score 9) and several gastric ulcers recovered all gastric regions (score 10).

\section{Statistical analysis}

Results are expressed as median \pm quartis (25 and 75). Differences among ulcer score were determined by Mann Whitney test. The number of animals with gastric ulcer incidences among the groups was determined by chi-square test.

\section{RESULTS AND DISCUSSION}

The anti-ulcer activity of aqueous and hydroethanol extract of aerial parts from Jodina rhombifolia on $\mathrm{HCl} / \mathrm{ethanol-induced} \mathrm{gastric} \mathrm{lesions} \mathrm{in}$ rat was evaluated and shows that $100 \%$ of the animals pre-treated with water, ranitidine $(100 \mathrm{mg} / \mathrm{kg})$ and the aqueous extract $(250$ or $750 \mathrm{mg} / \mathrm{kg}$ ) presented gastric lesions after the inductor agent administration. The pre-treatment with hydroethanol extract at 250 and 750 $\mathrm{mg} / \mathrm{kg}$ presented a significant reduction $(P<0.05$ : chisquare) of $75 \%$ and $62.5 \%$ in number of animals with gastric ulcers induced by $\mathrm{HCl} /$ ethanol. 
Therefore the hydroethanol extract inhibit the ulcer formation in 25.0 and $37.5 \%$ of the rats treated with 250 or $750 \mathrm{mg} / \mathrm{kg}$, respectively. The ulcer score presented in Figure 2 shows that all treatments (ranitidine, aqueous and hydroethanol extracts) were able to significantly reduce the ulcer score $(P<0.05$ : Kruskal Wallis). Ranitidine and both extracts (aqueous and hydroethanol at 250 and $750 \mathrm{mg} / \mathrm{kg}$ ) showed significant difference from the control group $(P<0.05$ : Mann Whitney) and both Jodina rhombifolia extracts presented similar ranitidine activity.

The chromatographic analysis of these active aqueous and hydroethanol extracts of the aerial parts revealed the predominance of compounds with typical behavior of flavonoids (fluorescence before and after sprying with Natural Product Reagent A); terpenoids and saponins were not detected by using the appropriate methodology usually employed in our laboratory (Taketa et al., 2004). After the fractionation of the hydroethanol extract by solvent extraction, the butanol fraction obtained was chromatographed with a silica gel column aiming the isolation and identification of compound 1 which was predominate. The UV spectrum data of compound 1 suggested the presence of a 5,7-dihydroxy derivative without orto hydroxyl groups, considering shifts induced by $\mathrm{NaOAc}, \mathrm{NaOAc} / \mathrm{H}_{3} \mathrm{BO}_{3}, \mathrm{AlCl}_{3}$ and $\mathrm{AlCl}_{3} / \mathrm{HCl}$. The ${ }^{13} \mathrm{C}$ NMR clearly indicated the presence of a C-glycoside derivative with two sugars. Detailed comparison with literature data for C-glycosylflavonoid (Lu \& Foo, 2000) allowed the identification of compound 1 as vicenin-2 (Figure 1). The signals of methods ${ }^{1} \mathrm{H}$ and ${ }^{13} \mathrm{C}$ NMR were full assigned and the assignments are according to those described by Lu \& Foo (2000) for vicenin-2. Further, three other C-glycosylflavonoids in the $n$-butanol fraction were identified as vitexin (compound 2), orientin (compound 3) and swertisin (compound 4) by direct comparison with authentic samples using two-dimensional TLC (Figure 1).

Considering the predominance of the C-glycosylflavonoid in the evaluated extract, the demonstrated anti-ulcer activity is probably related to the presence of these compounds.

The anti-ulcer cytoprotective effect have been described in animal experiments to some flavonoids as quercetin, amentoflavone and 3-methoxy 5,7,3',4'-tetrahydroxyflavan (Borowski, 1983; Gambhir et al., 1987; Havsteen, 1983). Coffigny et al. (2000) has demonstrated the anti-ulcer activity of the 2"-O-ramnosil 4"-O-metilvitexin of Pipper ossanum on gastric lesions induced by immobilization.

We concluded that the aqueous and hydroalcoholic extracts of Jodina rhombifolia present C-glycosylflavonoids as main components and demonstrate anti-ulcer properties by $\mathrm{HCl} /$ ethanolinduced protocol in Wistar rats. Further investigations are on going to determine the mechanism of anti-ulcer activity and the evaluations of the isolated glycosides in this model.

\section{ACKNOWLEDGMENTS}

Ana P. Dresch is indebted FAPERGS for the fellowship.<smiles>[R4]c1cc(-c2cc(=O)c3c(O)c([R3])c([R20])c([R])c3o2)ccc1O</smiles>

$\begin{array}{ccccc} & \mathrm{R} 1 & \mathrm{R} 2 & \mathrm{R} 3 & \mathrm{R} 4 \\ 1 & \mathrm{Glc} & \mathrm{H} & \mathrm{Glc} & \mathrm{H} \\ 2 & \mathrm{Glc} & \mathrm{H} & \mathrm{H} & \mathrm{H} \\ 3 & \mathrm{Glc} & \mathrm{H} & \mathrm{H} & \mathrm{OH} \\ 4 & \mathrm{H} & \mathrm{CH}_{3} & \mathrm{Glc} & \mathrm{H}\end{array}$

Figure 1. Chemical structures of C-glycosylflavonoids vicenin-2 (1); vitexin (2); orientin (3) and swertisin (4).

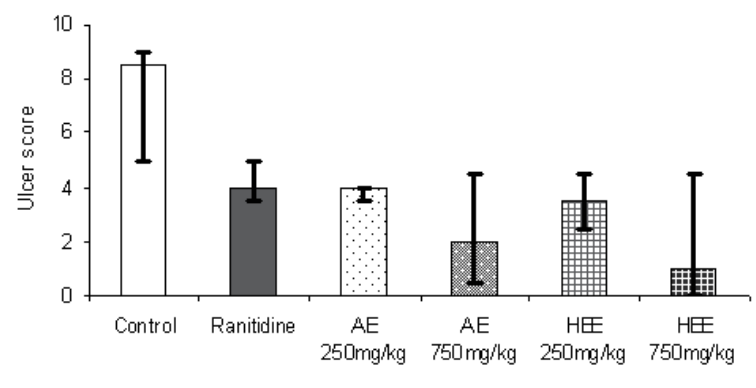

* $p<0,05$ : MannWhitne (dfference to contro)

Figure 2. Ulcer score induced by $\mathrm{HCl} /$ ethanol 30 minutes after pre-treatment with distillated water (Control), ranitidine (100 mg/kg), aqueous extract (250 or $750 \mathrm{mg} / \mathrm{kg} \mathrm{AE}$ ) or hydroethanol extracts ( 250 or $750 \mathrm{mg} / \mathrm{kg} \mathrm{HEE}$ ) of aerial parts from Jodina rhombifolia. $\mathrm{N}=8$ /group.

\section{REFERENCES}

Biavatti M, Marensi V, Leite SN, Reis A 2007. Ethnopharmacognostic survey on botanical compendia for potential cosmeceutic species from Atlantic Forest. Rev Bras Farmacogn 17: 640-653.

Borowski NA 1983. 3-Methoxy-5,7,3',4'-tetrahydroxyflavan. Drug Future 8: 209.

Coffigny MRA, Larionova IM, Rodriguez SS, Montalbi GA 2000. Evaluación de la actividad antiulcerosa del 2"-O-ramnosil 4"-O-metilvitexina de las hojas de Pipper ossanum. Rev Cubana Med Milit 29: 114117.

Corrêa MP 1969. Dicionário das Plantas Úteis do Brasil e das Exóticas Cultivadas VI. Rio de Janeiro: Instituto Brasileiro de Desenvolvimento Florestal. 
D’Avila MC 1910. Da Flora Medicinal do Rio Grande do Sul. Porto Alegre, 155p. Dissertação da cadeira de Historia Natural Medica - Faculdade de Medicina e Pharmacia, Universidade Federal do Rio Grande de Sul.

Gambhir SS, Goel RK, Das Gupta G 1987. Anti-inflamatory \& anti-ulcerogenic activity of amentoflavone. Indian $J$ Med Res 85: 689-693.

Havsteen B 1983. Flavonoids, a class of natural products of high pharmacological potency. Biochem Pharmacol 32: 1141-1148.

Lu Y, Foo LY 2000. Flavonoid and phenolic glycosides from Salvia officinalis. Phytochemistry 55: 263-267.

Simões CMO, Mentz LA, Schenkel EP, Irgang BE Stehmann JR 1998. Plantas da Medicina Popular no Rio Grande do Sul. $5^{\mathrm{a}}$ ed. Porto Alegre: Editora da Universidade.

Taketa ATC, Breitmaier E, Schenkel EP 2004. Triterpenes and triterpenoidal glycosides from the fruits of Ilex paraguariensis (Maté). J Braz Chem Soc 15: 205211.

Williamson EM, Okpako DT, Evans FE 1996. Selection, Preparation and Pharmacological Evaluation of Plant Material Vol. 1, New York: Wiley.

Yesilada E, Gurbuz I, Ergun E 1997. Effects of Cistus laurifolius L. flowers on gastric and duodenal lesions. J Ethnopharmacol 55: 201-211. 